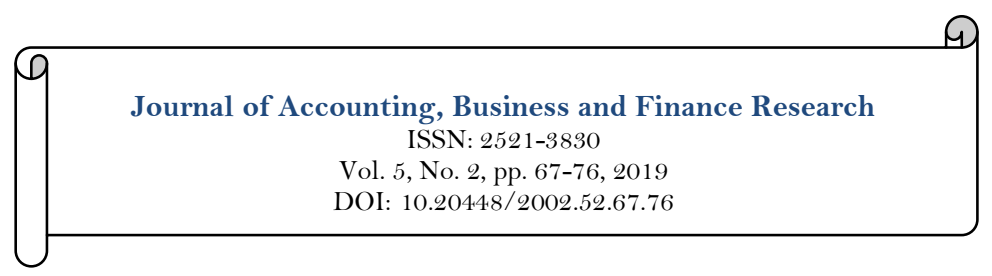

$\checkmark$ updates

\title{
Investigating the Impact of Sustainable Procurement on Economic Growth and Development
}

\author{
Benjamin Adelwini Bugri ${ }^{1}$ \\ Appiah Michael ${ }^{2 *}$ \\ Emmanuel Awusi Arthur ${ }^{3}$ \\ ${ }^{'}$ Department of Procurement and Supply Science Faculty of Business and Management Studies Koforidua Technical University Koforidua, \\ Ghana \\ 'School of Management Science $\&$ Engineering Department of Finance \& Economics Jiangsu University Zhenjiang, Jiangsu, China \\ Email:appiahjunior@yahoo.com \\ ${ }^{s}$ School of Management IPE Management School Paris, France
}

\begin{tabular}{l|l}
\multicolumn{3}{c}{ Abstract } \\
The usage of public procurement to accomplish economic growth and & Keywords: \\
development is extensive, but through evidence about its operations are often & Sustainable procurement \\
imprecise and challenging to discover. This study in effect is to look at the & Economic growth \\
impact and linkage between sustainable procurement and economic growth in & Ghana \\
Ghana from $1975-2015$. The article considers the Solow-Swan growth & VECM. \\
model and came out with the findings and a result that is consistent with most & \\
studies. It was realized that there is a positive and strong relationship as well & JEL Classification: \\
as the significant impact between sustainable procurement and economic & H57; O10; Q01. \\
growth. Also, it was recorded that trade openness can be a catalyst for & Licensed: \\
economic growth and development as the results proved there is a significant & This work is licensed under a \\
impact. A Johansen cointegration was employed to determine the long run & Creative Commons Attribution 4.0 \\
relationship between economic growth and sustainable procurement and it was & License. \\
found out that there exists a long run relationship. Vector Error Correction & Publisher: \\
Model was employed to study the long run and short run impact of sustainable & Scientific Publishing Institute \\
procurement on economic growth. The study also came out that recently, & \\
procurement is employed as a tool to promote economic growth as well as & \\
attain sustainable development goals. The study contains some reflections on & \\
the connections between procurement and economy, society and environment. &
\end{tabular}

Funding: There is no funding this research; the study was funded solely by the authors themselves.

Competing Interests: There is no competing interest in the conducting of this study.

\section{Introduction}

Developing countries are described by a deficient capital stock and lacking physical infrastructure, which, in turn, negatively influences economic competitiveness. Local industry ordinarily comes up short on the technological and productive ability to satisfy the capital need. Thusly, public procurement of foreign capital hardware and gear speaks to a significant offer of aggregate government outlays in many nations. Up to this point, the subject of public procurement was generally overlooked by development economists. Procurement was left to accountants, budget analysts, and operations management with an eye towards guaranteeing a stable supply chain, limiting expenses, and augmenting a thin arrangement of objectives (Taylor \& Yülek, 2012).

Sustainable procurement is a process whereby organizations, both government and private address their issues for goods, services, works and utilities in a way that achieves esteem for money on an entire life premise in wording of generating benefits not exclusively, to the association, yet likewise to society and the economy, while limiting harm to the environment (Forcee, 2006). 
This definition elaborates 'whole life basis' by affirming that "sustainable procurement should reflect the pillars of sustainable development which includes environmental, social and economic concerns of design; nonrenewable use of material; manufacturing and production systems; logistics; service distribution; use; operation; conservation; reuse; reprocessing options; disposal; and suppliers' abilities to address these concerns all through the supply chain" (Forcee, 2006).

In linkage with the European Union's Sustainable Development Strategy (EU SDS) (Kopps, 2006) genuine sustainable procurement should think about economic, environmental and social factors in breaking down the effect of sustainable procurement on the purchasing and supply chain environment. Most discussions, research and activity have concentrated on the environmental perspectives. This is justifiable as an underlying advance, yet any structure for investigation must think about the three mainstays of sustainability.

As of late public procurement has progressed toward becoming progressively in the center as an instrument of public policy notwithstanding its traditional job as a cornerstone of good governance. Sustainable Procurement (SP) becomes the overwhelming focus as a key indicator of governments' duty to sustainable development. Accomplishing sustainable development practically speaking requires that economic growth supports social advance just as protection of the environment, that economic execution strengthens social equity, and that environmental policy is financially savvy without bargaining the role of future generations. Governments ought to think about how to improve the utilization of procurement to achieve sustainability goals through adjusting the social, economic and environmental results of public procurement practices and choices. At the end of the day, they have to take part in "Sustainable Procurement".

To our understanding, there are inadequate databases that deal with cross-sectional and time series data on public procurement in emerging countries. However, most countries broadcast data relating to government procurements, public sector expenses, and imports. By noting the connection, these variables, we begin to realize the size of public procurement both international and domestic-among the emerging economies.

In this study, it investigates the impact of sustainable procurement on economic growth and development. In a developing country, governments are open to hold significant purchasing power in the economy, a list of options of both traditional and non-traditional procurement agreements that can support economic growth and development.

This study is structured as follows. In section 2, related literature on the subject was reviewed. In section 3 talks on data, methodology and estimation of results. The $4^{\text {th }}$ section presents empirical results and findings. Section five deals with the concluding remarks.

\section{Literature Review}

There have been a number of studies on public procurement which confirmed that procurement can foster economic growth and development but under certain conditions and criteria. These criteria and conditions may include well trained and skilled procurement officers with extensive knowledge on contracting options at their disposal and support of the economic planning committee to help in the direction on how to acquire scarce resources in a fair and efficient manner.

The size of public procurement is quite considerable. In Ghana, public authorities spend approximately 18 $\%$ as of 2014 as compared to $19 \%$ in 2015 of the country's GDP. In this manner, public procurement represents a significant part of the general demand for goods and services and is progressively observed as an attractive and feasible instrument for economic growth and development. Accordingly, a basic policy of public procurement can make a significant impact on a nation or industry. In actuality, public procurement has come to assume a major role in improving the quality level of the public and private sectors.

Monczka, Handfield, Giunipero, and Patterson (2015) and Burt, Petcavage, and Pinkerton (2010) have clarified the general perspective and qualities of public procurement in their works. Cohens, Nelson, and Walsh (2002) and Edlerr and Georghiou (2007) talked about the impact of public procurement on modern R\&D with Carterr, Kale, and Grimm (2000) tending to socially mindful purchasing practices. Rose and Palifka (2016) and Søreide (2002) explored the ethical issues of procurement. Likewise, Bhatnagars (2003) referenced e-Government and Fox, Ward, and Howard (2002) talked about social duty, with Beste (2008) examining green purchasing policy.

Again, McCruddens (2004) studied using procurement policy to stimulate social outcomes. He argues that at any rate in the social realm, the government has used its purchasing power in procurement to effect change in different markets since the nineteenth century. The twentieth century is peppered with various overall instances of procurement restriction ranging from hostile to discrimination clauses (gender, race, disability) to environmental guidelines (green procurement). So while the government is often connected with administrative routines to restrict or eliminate activities regarded unwanted, public procurement can likewise foster market creation that is reasonable and sustainable.

Watermeyerr (2000), Boltonn (2006) and Lii (2013) survey the encounters of the European Community, South Africa, and China individually and make positive inferences with respect to open procurement and development linkages. They give proof of effective linkages that made jobs, active technology transfers and innovation and tended to racial and regional inequalities more productively than different mechanisms. 
Edlerr and Georghiou (2007) and Geroskii (1990) audit the exact proof on public procurement as an instrument for innovation and discover wide help. The examinations - which utilize both quantitative and qualitative methodologies - happened more than four decades (yet just intermittently) and are strikingly predictable in their results. Public procurement linkages, while raising fixed, variable, and transaction costs at any rate, ostensibly produce a higher number of innovations per dollar spent contrasted with different policies. Procurement linkages produce prevalent innovation motivations (over a more extended time skyline) and are in this way "an unquestionably more efficient instrument to use in stimulating innovation than any of aside scope of as often as possible utilized R\&D endowments" Geroskii (1990).

These results regardless, the evidence is mixed and lacking formal audits. For instance, Brauer and Dunne (2004) is incredulous of any net benefits from procurement linkages, and Hainess (2012) offers case, ponder evidence of inefficient outcomes in an unmistakable South African task from the late 1990s. All things considered, Boltonn (2006) keeps up that "in general, acquisition as a strategic instrument can be legitimized," what's more, Arrowsmiths (2002) recognizes "where legitimately utilized, [public] procurement may demonstrate a helpful and effective instrument... [And is] a substantial and valuable device for the implementation of social arrangements; and one which ought not to be denied to the government [s] without persuading justification."

\subsection{Public Procurement Regulations in Ghana}

Before the changes of the public procurement framework in Ghana, there was the nonattendance of a complete public procurement policy, absence of extensive legal framework or routine to safe guide the honesty of public procurement framework, nonappearance of a focal body with the imperative ability, technical mastery and capability to build up an intelligent public procurement policy. The changes of the public procurement system in Ghana started in 1996 as a fundamental piece of a more extensive Public Financial Management Reform Programme (PUFMAP). The goal of the activity was to improve the general administration of public finance in the nation (Ameyaws, Mensah, \& Osei-Tutu, 2012).

The regulatory agent of public procurement in Ghana is the Public Procurement Authority, likewise alluded to as the Public Procurement Board built up by the Public Procurement Act 2003, Act 663. The goal of the Board as indicated by the Public Procurement Act (2003) cited by Ameyaws et al. (2012) is to - harmonize the procedures of public procurement in the public service to verify a prudent, economic and effective utilization of state assets in public procurement and guarantee that public procurement is completed in a fair, clear and unbiased way. Part 1, Section 3 of the Act highlights the roles of the Board.

Sarfoo and Baah-Mintah (2013) have demonstrated that the Act has achieved decency, competition, proficiency, viability in the honour of government contracts. The researchers likewise demonstrate that there has been transparency in the honour of contracts since the introduction of the Act.

\subsection{Procurement and Sustainability}

\subsubsection{Procurement and Economic Development}

Economic development goals are progressively an element of procurement (Gordon, 2009). In particular, scholars have progressively talked about the role of procurement as an economic development device and as a driver of innovation (Edlerr \& Georghiou, 2007; Uyarra \& Flanagan, 2010). Hemenway (1989) for instance, depicts how a 1980 s exertion towards extensive scale installation in public vehicles leads to the birthplace of vehicular airbags as a standard ware. After two decades, (Edlerr \& Georghiou, 2007) investigation of more than 1000 firm is and 25 federations found that more than 50 percent of respondents indicated extended market demand as the primary driver of innovation.

Governments' have talked about and actualized municipal procurement and broadly incorporate economic development goals into procurement choices by focusing on local businesses through "buy-local" campaigns. Rising policies may create as governments look to reinforce work inside their wards and explicitly as for example "Buy America" arrangements are incorporated into America Resource and Recovery Act and other subsidizing bundles. Given the ongoing economic emergency, utilizing procurement to invigorate the local economy might be an attractive and opportunistic move for governments chasing to achieve such external goals (Gordon, 2009).

\subsubsection{Procurement and Social Equity}

Drawing on nurturing economic opportunities as a key outer goal in procurement, for model purchase local organizations can be explicitly made as an instrument to intercede equity worries by focusing on economic opportunities at specific gatherings as far as geography, history disservices in economic opportunities, or unbalanced economic need. Researchers, including McCruddens (2004) have noticed the historical origins of the equity and social justice measurements of procurement.

All the more as of late, strategies' identified with this exertion have incorporated the institution of minority-owned business necessities in procurement arrangements by requiring contractors to explicitly connect with minority and women-owned businesses as subcontractors, or through giving extra indicates to minority and business owned contractors or subcontractors inside the evaluation of reactions to offers. The 
research proposes that such arrangements have been received in an assortment of locals so as to integrate equity and economic values into the outside goals of local procurement.

\subsubsection{Procurement and Environment}

Following the 2002 World Summit on Sustainable Development, environmental goalies have been integrated into policy through procurement (Preuss, 2009; Walker \& Brammer, 2009). Sustainable procurement is characterized as purchasing, "products or services that have a lesser or decreased impact on human health and the environment when contrasted and contending products or services that fill a similar need" (Kaye \& Worrel, 2012). The research proposes that numerous local governments have actualized official policies, permitting and in some cases commanding, municipal purchasing departments to apply environmental considerations to procurement activities. Projects differ on plan and usage, however, for the most part, requires buying items with a higher level of reused substance, procuring sustainable power source, and purchasing less poisonous items and vitality proficient machines. The Environmental Protection Agency refers to a few instances of local purchasing programs as especially successful (Bruskotter, 2010; Marqusee, 2010).

\section{Data, Methodology and Estimation of Results}

\subsection{The Data Set and Description}

The data set used in this study entails time series covering 1975 to 2015 . The variables under discussion are: Economic Growth and development (GDPPC) proxied by Gross Domestic Product per Capita; Capital (CAP) proxied by Government Capital Formation; Education (EDU); Inflation (INF) proxies as the Consumer Price Index; Sustainable Procurement (PRO) proxied by government final consumption expenditure and trade. The variables are obtained from the World Bank's World Development Indicators edition online (Bank, 2019) Barro and Lee Database (Barro \& Lee, 1994).

\subsection{Methodology}

This study investigates the impact of sustainable procurement proxied by government final consumption expenditure on economic growth and development in Ghana. This is to establish if a sustainable procurement in Ghana during the years under revision has positively impacted significantly in achieving economic growth and development in Ghana.

\subsection{Model Specification}

In order to study the impact of Sustainable Procurement (PRO) on economic growth and development (GDP), a relationship linear function of the form is established;

Linearizing the above Equation 1 we have;

$$
\mathrm{GDP}=\mathrm{F}(\mathrm{CAP}, \mathrm{EDU}, \mathrm{INF}, \mathrm{PRO}, \mathrm{TRADE}) \ldots \ldots .(1)
$$

$$
G D P t=\alpha t+\beta_{1} C A P t+\beta_{2} E D U t+\beta_{3} I N F t+\beta_{4} P R O t+\beta_{5} T R A D E t+E t \ldots E q n(2)
$$

A natural $\log$ is employed on all the variables which is denoted in Equation 3 below as:

Where;

$$
\ln G D P t=\alpha t+\beta_{1} \ln C A P t+\beta_{2} \ln E D U t+\beta_{3} \operatorname{lnINFt}+\beta_{4} \operatorname{lnPROt}+\beta_{5} \ln T R A D E t+\varepsilon t \ldots . . E q n(3)
$$

GDPt: Gross Domestic Product at time t

CAPt: Government Capital Formation at time $t$

EDUt: Education at time $\mathrm{t}$

INFt Inflation at time $t$

PROt: Sustainable Procurement at time $t$

TRADEt: Trade Openness at time $\mathrm{t}$

Et: Error Term

$\beta_{1}$ : intercept, $\beta_{1}, \beta_{2}, \beta_{3}, \beta_{4}, \beta_{5}<0 ; \beta_{5}$, >0 based on a priority expectation.

\subsection{Model Estimation}

The method of estimation will be purely econometric using Vector Error Correction Model (VECM). To assess the reliability and validity of econometric model, the coefficient of determination, R-Square $\left(\mathrm{R}^{2}\right)$, standard Error test, F-test, Unit root test, cointegration test and Durbin Watson test shall be estimated.

\subsection{The coefficient of Determination ( $R$-Square $\left(R^{2}\right)$}

The R-Square $\left(\mathrm{R}^{2}\right)$ which is the coefficient of determination is a degree of goodness of model fitness in the regression. It estimates the total variation percentage of the dependent variable as explained by the independent variable. 
3.6. Fisher F-Test

The F-test is another econometric criterion to determine the overall significance and stability as well as the coefficients of the model.

To ascertain the relations which exist between the dependent variable and the independent variables a Pairwise Correlation was assessed in Table 1.

Table-1. Correlation and Correlation Significant Matrix

\begin{tabular}{|c|c|c|c|c|c|c|}
\hline \multicolumn{2}{|c|}{ Correlation } & \multirow[b]{2}{*}{ LNCAP } & \multirow[b]{2}{*}{ LNEDU } & \multirow[b]{2}{*}{ LNINF } & \multirow[b]{2}{*}{ LNPRO } & \multirow[b]{2}{*}{ LNTRADE } \\
\hline Probability & LNGDP & & & & & \\
\hline \multirow[t]{2}{*}{ LNGDP } & 1.000000 & & & & & \\
\hline & --- & & & & & \\
\hline \multirow[t]{2}{*}{ LNCAP } & 0.466741 & 1.000000 & & & & \\
\hline & $0.0021^{* * * *}$ & -- & & & & \\
\hline \multirow[t]{2}{*}{ LNEDU } & 0.695987 & 0.744514 & 1.000000 & & & \\
\hline & $0.0000^{* * * *}$ & $0.0000^{* * * *}$ & --- & & & \\
\hline \multirow[t]{2}{*}{ LNINF } & 0.658657 & 0.811449 & 0.905124 & 1.000000 & & \\
\hline & $0.0000^{* * * *}$ & $0.0000^{* * * *}$ & $0.0000^{* * * *}$ & --- & & \\
\hline \multirow[t]{2}{*}{ LNPRO } & 0.947659 & 0.693566 & 0.806449 & 0.782066 & 1.000000 & \\
\hline & $0.0000^{* * * *}$ & $0.0000^{* * * *}$ & $0.0000^{* * * *}$ & $0.0000^{* * * *}$ & ---- & \\
\hline \multirow[t]{2}{*}{ LNTRADE } & 0.392589 & 0.962840 & 0.739803 & 0.798803 & 0.630863 & 1.000000 \\
\hline & $0.0111^{* *}$ & $0.0000^{* * * *}$ & $0.0000^{* * * *}$ & $0.0000^{* * *} *$ & $0.0000^{* * *} *$ & -- \\
\hline
\end{tabular}

Note: $1 .(* *),(* *)$ and $(*)$ indicate statistical significance at $1 \%, 5 \%$ and $10 \%$ respectively.

\section{Unit Root Test}

In most literature, macroeconomic variables are trended and therefore are non-stationary. Using nonstationary data to estimate a model leads to spurious results (Granger, 2001; Hayo, 1971). The 1st and 2nd difference terms of the data will generally be stationary (Hayo, 1971). In this study, all variables will be estimated at levels and the first difference for stationarity using Augmented Dickey-Fuller (ADF) and Phillips-Perron Test See Table 2. 
Table-2. Unit Root Estimation results.

\begin{tabular}{|c|c|c|c|c|c|c|c|c|}
\hline \multirow[b]{2}{*}{ Variable } & \multicolumn{2}{|c|}{ ADF Level } & \multicolumn{2}{|c|}{ Phillips-Perron Level } & \multicolumn{2}{|c|}{ ADF, 1st Difference } & \multicolumn{2}{|c|}{ Phillips-Perron $1^{\text {st }}$ Difference } \\
\hline & Cons & Cons \& Trend & Cons & Cons \& Trend & Cons & Cons \& Trend & Cons & Cons \& Trend \\
\hline LNGDP & -0.274564 & -1.592603 & -0.419218 & -1.427027 & $-4.970838 * * *$ & $-4.932637 * * *$ & $-4.989190^{* * * *}$ & $-4.946772^{* * * *}$ \\
\hline LNCAP & -1.095086 & -2.682404 & -1.095086 & -2.728299 & $-6.968675^{* * * *}$ & $-6.849599^{* * * *}$ & $-7.025939^{* * * *}$ & $-6.899530 * * *$ \\
\hline LNEDU & -1.247213 & $-8.196986^{* * *}$ & -1.972232 & $-13.14502 * * *$ & $-11.26735^{* * * *}$ & $-11.10658^{*} * *$ & $-28.27776^{* * * *}$ & $-28.21990 * * *$ \\
\hline LNINF & -6.821098 & -2.913399 & $-8.177090 * * *$ & $-3.674440^{* * *}$ & $-2.806310^{*}$ & $-6.144628 * * *$ & $-3.718442^{* * * *}$ & $-6.146407 * * *$ \\
\hline LNPRO & -0.281261 & -2.043233 & 0.438458 & -1.610120 & $-4.420439 * * *$ & $-4.459413^{* * * *}$ & $-4.194425^{* * * *}$ & $-4.537573^{* * * *}$ \\
\hline LNTRADE & -1.081902 & -2.886852 & -0.818522 & -2.432470 & $-4.995987 * * *$ & $-4.907791 * * *$ & $-4.002224 * * * *$ & $-3.938571^{* *}$ \\
\hline
\end{tabular}

Note: 1 ADF \& Phillips-Perron unit root. (****).(**) and (*) indicate statistical significance at $1 \%, 5 \%$ and $10 \%$ respectively. 
Cointegration Test

The idea of cointegration is developed to reduce the problem of spurious correlation usually related to non-stationary macroeconomic data. According to Mills and Mills (1991) cointegration determines the long run relationship and the theory of steady-state equilibrium. Komolafe (1996) stated that the idea of cointegration is that two different series might not be stationary; some linear grouping may be stationary with more than two series.

Table-3. Cointegration Matrix.

\begin{tabular}{c|c|c|c|c}
\hline Hypothesized & & Trace & 0.05 & \\
\hline No. Of CE(s) & Eigenvalue & Statistic & Critical Value & Prob. $^{*} *$ \\
\hline None $^{*}$ & 0.734101 & 126.4684 & 95.75366 & 0.0001 \\
\hline At most 1 & 0.585580 & 76.13208 & 69.81889 & 0.0143 \\
\hline At most 2 & 0.417611 & 42.65885 & 47.85613 & 0.1411 \\
\hline At most 3 & 0.313400 & 22.11539 & 29.79707 & 0.2921 \\
\hline At most 4 & 0.181418 & 7.827254 & 15.49471 & 0.4840 \\
\hline At most 5 & O.005782 & 0.220372 & 3.841466 & 0.6388 \\
\hline Trace test indicates 2 cointegrating eqn(s) at the 0.05 level. & & &
\end{tabular}

Vector error correction model (VECM) was estimated to determine the long run coefficient and significance between the dependent and independent variables. The table below gives the VECM statistics.

Table-4. VECM Matrix

\begin{tabular}{c|c|c|c|c}
\hline Variable & Coefficient & Std. Error & t-Statistic & Prob. \\
\hline D (LNCAP) & -0.167950 & 0.115212 & -1.457755 & 0.1564 \\
\hline D (LNEDU) & -0.019818 & 0.049947 & -0.396779 & 0.6946 \\
\hline D (LNINF) & 0.010203 & 0.115381 & 0.088431 & 0.9302 \\
\hline D (LNPRO) & 0.628269 & 0.094801 & 6.627250 & 0.0000 \\
\hline D (LNTRADE) & -0.168201 & 0.092728 & -1.813913 & 0.0808 \\
\hline C & -0.005443 & 0.040145 & -0.135586 & 0.8932 \\
\hline R-squared & 0.704050 & Mean dependent var & 0.040926 \\
\hline Adjusted R-squared & 0.583478 & S.D. dependent var & 0.163294 \\
\hline S.E. of regression & 0.105387 & Akaike info criterion & -1.414688 \\
\hline Sum squared resid & 0.299876 & \multicolumn{5}{|c}{ Schwarz criterion } & -0.902823 \\
\hline Log likelihood & 39.58641 & Hannan-Quinn criteria. & -1.231035 \\
\hline F-statistic & 5.839237 & Durbin-Watson stat & 1.907115 \\
\hline Prob (F-statistic) & 0.000091 & \multicolumn{5}{l}{}
\end{tabular}

\section{Empirical Findings and Results}

\subsection{Unit Root Test Result Analysis}

In a recent development with modelling time series data, unit root test is mainly required to determine whether the time series variables are stationary or non-stationary. This test of the strategy to reduce the risk of spurious estimations (Engle \& Granger, 1987; Granger, 2001). Usually using 1st Differencing bounds the variable to stationary if they are not stationary. As displayed in Table 2 , the unit root test indicates that the null hypothesis can be rejected after the 1 st Difference I (1) for the variables $1 \%$ significance level. This is evidence that the study did not reject the null at Level but rather accepted the null hypothesis at level series, specifying that the variables are stationary at level but became non-stationary after 1st Difference.

The notion of cointegration verifiable agrees to linearity and symmetry, which implies that the change of the deviations towards the long-run balance is made quickly at every period and increments or declines of the deviations are rectified similarly. The test of cointegration is fundamentally to set up a long-run relationship between non-stationary variables (Piłatowska, Włodarczyk, \& Zawada, 2015). A Johansen Cointegration procedure was estimated in this examination and from the results above in Table 3 indicates that there is cointegrating between the variables with two cointegration equations at $5 \%$ significance level.

\subsection{Vecm Result Analysis}

The parsimonious VECM results displayed in Table 4 gives the long run coefficient and the significance of the independent variables on the dependent variables.

It can be seen from the table above that Capital formation has no significant on economic growth and development and also recorded a negative relationship between them. This result is consistent with a study by Kendrick (1993) who pointed out that "formation of capital alone does not lead to economic prosperity". Again (Blomstrom, Lipsey, \& Zejan, 1993) also confirmed this results in their study "Is Fixed Investment the Key to 
Economic Growth?,". This finding and results contradict a study by Levine and Renelt (1992) who recorded that "there is a positive, robust correlation between growth and the share of investment in GDP."

The results indicated above displays that Education which is a common barometer of economic growth and development recorded non-significant effects. It can be noted that under the year of discussion secondary education did not play any significant role in the growth and development of the economy in Ghana. This hypothesis is supported by an investigation from Pritchett (1999). Again, Glewwe, Maiga, and Zheng (2014) confirmed the findings in a study on "The Contribution of Education to Economic Growth: A Review of the Evidence, with Special Attention and an Application to Sub-Saharan Africa". The results are inconsistent with that of Barro (1991) and who recorded that "both primary and secondary (gross) enrolment rates have significantly positive impacts on the rate of economic growth"

Most African economies are faced with a high rate of inflation and Ghana is no exception, from the results above, inflation has no significant effects on economic growth and development. Most research has indicated that inflation brings down growth and development in an economy (Barro, 1995; Cardoso, 1992; Fischer, 1993).

On the issue of government expenditure, thus sustainable procurement which is the variety of interest, it can be seen that there are a positive sign and relationship between sustainable procurement and economic growth. This is seen that a unit increases in the purchase of goods and services which do not degrade the environment will equally lead to $99 \%$ increase in economic growth and development. This is explained as when more and more of government expenditure are towards the provision of good economic, environmental and social services there is a direct relation to economic growth and development. This result is confirmed in a study by Wu, Tang, and Lin (2010) and Aschauer (1990) which contradicts a study conducted which recorded that "government spending is not related with economic growth" This result is also supported by Yasin (2011) when he investigated on "public spending and economic growth: empirical investigation of sub-Saharan Africa"

Trade is the summation of exports and imports as a portion of GDP, from the results above it can be seen that it has a positive significant on economic growth and development with a prob value of 0.0808 at a $10 \%$ significant value. This result is supported by a study conducted by Aschauere (1989). Also, Koskei, Buigut, and Kibet (2013) confirmed this hypothesis in his investigation on "Impact of openness, foreign direct investment, gross capital formation on economic growth."

\subsection{Results on Model Fitness}

1. The R-squared $\left(\mathrm{R}^{2}\right)$ is 0.704050 thus $70 \%$. It concludes that capital formation, education, sustainable procurement, inflation and trade explains $70 \%$ systematic variations in, economic growth and development between 1975-2015 in Ghana. This result indicates goodness in model fitness.

2. The Prob (F-statistic) of 0.0000 is significant at the $1 \%$ significance level and it indicates that the descriptive variables are important determinants of economic growth and development.

3. The value of Durbin Watson is 1.907115 for the model. This falls within the determined area and suggests the negative $1^{\text {st }}$ order serial autocorrelation among the descriptive variables in the model.

\section{Conclusion}

The purpose of this study was to investigate the link and impact between sustainable procurement and economic growth and what's more, to reveal some insight into how sustainable procurement can be utilized as a policy tool for fast development in Ghana. Sustainable procurement reforms and regulations in Ghana was talked about.

Using a modified Solow-Swan growth model, the study revealed that sustainable procurement is a strong factor for economic growth and development, thus there is a positive relationship and significant between the two variables of interest. It contended that the moderate pace of advancement Ghana could be credited mostly to feeble/broken public procurement frameworks and rehearses and along these lines prescribed profitable/sound public procurement system as a panacea to the weak economies of Ghana.

The Measures prescribed to support the public procurement systems in Ghana incorporate political will with respect to the government to guarantee that planned aggregates are utilized for the proposed purposes; solid pledge to battling corruption; strict adherence to the legal system regulating procurement rehearses; limit working through training and retraining of procurement staff of procuring substances, and so forth.

The soundness or shortcoming of the public procurement system consequently reflects the nature of governance in the general public. Sound public procurement framework is an impression of good governance, while the powerless public procurement framework is an impression of terrible governance. Great governance and sound public procurement framework are a subsequently indispensable element for sustainable growth and development of an economy 


\section{References}

Ameyaws, C., Mensah, S., \& Osei-Tutu, E. (2012). Public procurement in Ghana: the implementation challenges to the public procurement law 2003 (Act 663). International Journal of Construction supply chain management, 2(2), 55-65.

Arrowsmiths, S. (2002). Public procurement as an instrument of policy and the impact of market liberalisation. International Library of Critical Writings in Economics, 144, 445-494.

Aschauer, D. A. (1990). Is government spending stimulative? Contemporary Economic Policy, 8(4), 30-46.

Aschauere, D. A. (1989). Is public expenditure productive? Journal of Monetary Economics, 23(2), 177-200.

Bank, W. (2019). World Bank development indicators. Retrieved from https://data.worldbank.org/.

Barro, R. J. (1991). Economic growth in a cross section of countries. The Quarterly Journal of Economics, 106(2), 407-443.

Barro, R. J. (1995). Inflation and economic growth (No. w5326). National Bureau of Economic Research.

Barro, R. J., \& Lee, J. W. (1994). Data set for a panel of 138 countries. In: Harvard Univ.

Beste, T. (2008). Greening the supply chain in public procurement: A case study of UK local authority.

Bhatnagars, S. (2003). E-government and access to information. Global Corruption Report, 24-32.

Blomstrom, M., Lipsey, R. E., \& Zejan, M. (1993). Is fixed investment the key to economic growth? (No. w4436). National Bureau of Economic Research.

Boltonn, P. (2006). Government procurement as a policy tool in South Africa. Journal of Public Procurement, 6(3), $193-217$.

Brauer, J., \& Dunne, P. (2004). Arms trade and economic development: Theory, policy and cases in arms trade offsets: Routledge.

Bruskotter, K. (2010). Discussion with Karl Bruskotter regarding procurement in City of Santa Monica. 6.

Burt, D. N., Petcavage, S. D., \& Pinkerton, R. L. (2010). Supply management. New York: McGraw-Hill.

Cardoso, E. (1992). Inflation and poverty (No. w4006). National Bureau of Economic Research.

Carterr, C. R., Kale, R., \& Grimm, C. M. (2000). Environmental purchasing and firm performance: An empirical investigation. Transportation Research Part E: Logistics and Transportation Review, 36(3), 219-228.

Cohens, W. M., Nelson, R. R., \& Walsh, J. P. (2002). Links and impacts: The influence of public research on industrial R\&D. Management Science, 48(1), 1-23.

Edlerr, J., \& Georghiou, L. (2007). Public procurement and innovation-Resurrecting the demand side. Research Policy, 36(7), 949-963.

Engle, R. F., \& Granger, C. W. J. (1987). Co-integration and error correction: Representation, estimation, and testing. Econometrica, 55(2), 251-276.

Fischer, S. (1993). The role of macroeconomic factors in growth. Journal of Monetary Economics, 32(3), 485-512.

Forcee, S. P. T. (2006). Procuring the future. London: Sustainable Procurement Task Force.

Fox, T., Ward, H., \& Howard, B. (2002). Public sector roles in strengthening corporate social responsibility: A baseline study; Corporate Responsibility for Environment and Development Programme. International Institute for Environment and Development (IIED).

Geroskii, P. A. (1990). Procurement policy as a tool of industrial policy. International Review of Applied Economics, 4(2), 182198.

Glewwe, P., Maiga, E., \& Zheng, H. (2014). The contribution of education to economic growth: A review of the evidence, with special attention and an application to Sub-Saharan Africa. World Development, 59, 379-393.

Gordon, M. J. (2009). Improving the validity of public procurement research. International Journal of Public Sector Management, 22(2), 91-103.

Granger, C. W. (2001). Essays in econometrics: Collected papers of Clive WJ Granger: Cambridge University Press. 2.

Hainess, R. (2012). The complexities of development: The South African national industrial participation programme in perspective. In Designing Public Procurement Policy in Developing Countries (pp. 111-139): Springer.

Hayo, B. (1971). Applied econometrics.

Hemenway, D. (1989). Government procurement leverage. Journal of Public Health Policy, 1O(1), 123-125.

Kaye, N. L., \& Worrel, G. (2012). Procurement for sustainable local economic development. International Journal of Public Sector Management, 25(2), 133-153.

Kendrick, J. W. (1993). How much does capital explain? Contributions to Economic Analysis, 214, 129-129.

Komolafe, O. S. (1996). Cointegration theory: Technique and application. Macroeconomic policy analysis, tools, technique and application to Nigeria Ibadan: NCEMA. 301-320

Kopps, U. (2006). The EU SDS process. ESDN Quarterly Report, 5.

Koskei, N. S. I., Buigut, K., \& Kibet, J. (2013). Impact of openness, foreign direct investment, gross capital formation on economic growth in Kenya.

Levine, R., \& Renelt, D. (1992). A sensitivity analysis of cross-country regressions. American Economic Review, 82(2), 942963.

Lii, Y. (2013). Public procurement as a demand-side innovation policy in China: An exploratory and evaluative study. Doctoral Dissertation, University of Manchester.

Marqusee, R. J. P. C. (2010). Telephone interview with the director of economic development of Woodbury County, Iowa. 5 .

McCruddens, C. (2004). Using public procurement to achieve social outcomes. Paper presented at the Paper Presented at the Natural Resources Forum.

Mills, T. C., \& Mills, T. C. (1991). Time series techniques for economists: Cambridge University Press.

Monczka, R. M., Handfield, R. B., Giunipero, L. C., \& Patterson, J. L. (2015). Purchasing and supply chain management. Mason, OH: Cengage Learning.

Piłatowska, M., Włodarczyk, A., \& Zawada, M. (2015). CO 2 emissions, energy consumption and economic growth in the EU countries: Evidence from threshold cointegration analysis.

Preuss, L. (2009). Addressing sustainable development through public procurement: The case of local government. Supply Chain Management: An International Journal, 14(3), 213-223.

Pritchett, L. (1999). Where has all the education gone? : The World Bank. 
Rose, A. S., \& Palifka, B. J. (2016). Corruption and government: Causes, consequences, and reform. Cambridge University Press. Sarfoo, P. A., \& Baah-Mintah, R. (2013). Assessing the effect of the procurement act (663) on the public financial management in Ashanti Region. American Journal of Rural Development, 1(4), 91-98.

Søreide, T. (2002). Corruption in public procurement. Causes, consequences and cures: Chr. Michelsen Intitute.

Taylor, T. K., \& Yülek, M. A. (2012). Leveraging international public procurement in support economic development: Forecasting public sector expenditures and market size in Turkey. Paper presented at the 5th The International Public Procurement Conference, USA, Çevrimiçi Erişim Adresi.

Uyarra, E., \& Flanagan, K. (2010). Understanding the innovation impacts of public procurement. European Planning Studies, 18(1), 123-143.

Walker, H., \& Brammer, S. (2009). Sustainable procurement in the United Kingdom public sector. Supply Chain Management: An International Journal, 14(2), 128-137.

Watermeyerr, R. (2000). The use of targeted procurement as an instrument of poverty alleviation and job creation in infrastructure projects. Public Procurement Law Review, 226-250.

Wu, S. Y., Tang, J. H., \& Lin, E. S. (2010). The impact of government expenditure on economic growth: How sensitive to the level of development? Journal of Policy Modeling, 32(6), 804-817.

Yasin, M. (2011). Public spending and economic growth: Empirical investigation of Sub-Saharan Africa. South-western Economic Review, 30, 59-68. 